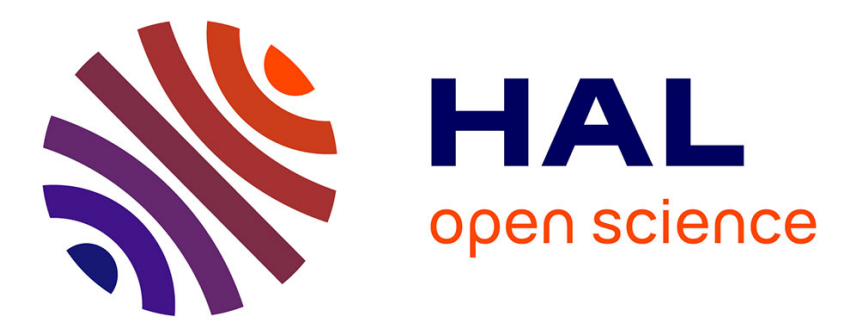

\title{
Comparing the Effects of Using a Tangible Object or a Simulation in Learning Elementary CS Concepts
}

\author{
Grégoire Fessard, Ilaria Renna, Patrick Wang
}

\section{To cite this version:}

Grégoire Fessard, Ilaria Renna, Patrick Wang. Comparing the Effects of Using a Tangible Object or a Simulation in Learning Elementary CS Concepts. 50th ACM SIGCSE Technical Symposium on Computer Science Education (SIGCSE '19), Feb 2019, Minneapolis, MN, United States. pp.1274-1274, 10.1145/3287324.3293809 . hal-02156180

\section{HAL Id: hal-02156180 \\ https://hal.science/hal-02156180}

Submitted on 14 Jun 2019

HAL is a multi-disciplinary open access archive for the deposit and dissemination of scientific research documents, whether they are published or not. The documents may come from teaching and research institutions in France or abroad, or from public or private research centers.
L'archive ouverte pluridisciplinaire HAL, est destinée au dépôt et à la diffusion de documents scientifiques de niveau recherche, publiés ou non, émanant des établissements d'enseignement et de recherche français ou étrangers, des laboratoires publics ou privés. 


\section{Comparing the Effects of Using a Tangible Object or a Simulation in Learning Elementary CS Concepts: a Case Study with Block-Based Programming}

Grégoire Fessard, Institut Supérieur d'Électronique de Paris

Ilaria Renna, Institut Supérieur d'Électronique de Paris Patrick Wang, Institut Supérieur d'Électronique de Paris Contact: gregoire.fessard@gmail.com

Learning elementary Computer Science (CS) concepts can often be difficult for young students. The literature presents two main practices to introduce programming: using digital environments (e.g., integrated development environments, command-line tools) or exploiting manipulations on programmable tangible objects such as robots. This second practice has recently gained traction thanks to the positive results concerning the use of programmable objects in introductory programming courses. However, and to the best of our knowledge, there is no study comparing learning gains between 'digital' and 'physical' computing.

Our study focuses on highlighting possible differences between these two practices to learn CS at an introductory level. We compare the learning progress of two groups of students (total=36, male $=27$, female $=9$, aged 14-17) with little or no previous knowledge of programming; both groups are presented with the same pre-test, programming exercises, and post-test. All participants exploit a blockbased programming environment to do the exercises and program either a tangible BBC micro:bit card or its digital simulation. The proposed programming exercises concern basic CS concepts: variables, conditional structures, and iterative structures. By running their programs on the tangible or digital card, students are able to visualize the results of their exercises thanks to the grid of LEDs that is present on the BBC micro:bit.

Our objective is to determine if the learning of a specific CS concept is better achieved through the programming of a tangible object or an exact equivalent digital simulation of it.

A statistical analysis will be presented to evaluate the results of this experiment.

Keywords: Computer Science Education; Physical Computing; Digital Computing; Block-Based Programming

DOI: https://doi.org/10.1145/3287324.3293809

CCS Concepts: Authors, this ACM Classification section will be collected on the Sheridan submission page. You do NOT have to include these here. The submission page will lead you to: http://dl.acm.org/ccs_flat.cfm 